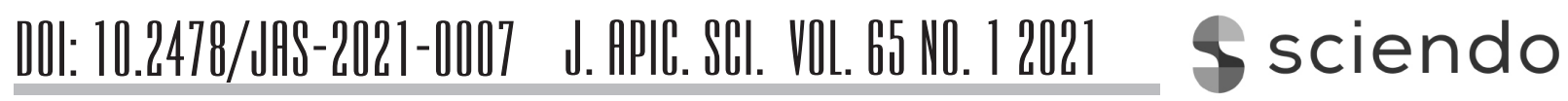

Original Article

\title{
FIRST RECORD OF ASCOSPHAERA APIS ISOLATED FROM COMMERCIAL POLLEN FROM NORTHERN ARGENTINIAN PROVINCES
}

\author{
Marcos R. Tejerina* \\ Marcelo R. Benitez-Ahrendts \\ Universidad Nacional de Jujuy, Facultad de Ciencias Agrarias \\ *corresponding author: tejerina.marcos@yahoo.com \\ Received: 16 July 2020; accepted: 14 February 2021
}

A bstract

In recent years, increased deforestation and replacement of areas intended for intensive cultivation have caused pathogens and parasites of Apis mellifera bees to emerge in regions where they had not previously been reported. Such is the case of the advancement of Ascosphaera apis, a fungus that causes a drop in colonies' bee larvae population and great economic losses to beekeeping activity during severe cases. In northern Argentina, few studies have focused on this important entomopathogen. This is the first study on A. apis isolated from commercial pollen in Entre Ríos, Jujuy, and Misiones provinces, where its prevalence in bee colonies has not been reported. We identified this entomopathogen using macroscopic, microscopic, and molecular analyses, focusing on its botanical origin as a possible transmission route. We found the pathogenicity of each strain in $A$. mellifera bees to below $30 \%$. The results of this study contribute to the promotion of sanitary measures that may reduce this disease's progression in local apiaries.

Keywords: Apis mellifera, chalk brood, pathogenicity, pollen

\section{INTRODUCTION}

Bees play an important ecological role worldwide since they pollinate numerous crops and wild plants and an economic role in agriculture. The pollination of such fruit and vegetable crops as apple, pear, melon, strawberry, onion, pea, asparagus, celery, cotton and alfalfa depend on populations of domestic bees or other native, wild, solitary, or social species (Ollerton et al., 2010; Koh et al., 2016). Bees in hive are continuously exposed to pathogens affecting their populations in winter, low temperatures, increased humidity, shortages of pollinic resources, hive movements and deficient health management carried out by beekeepers. These factors predispose bees to the action of pathogens and parasites that affect the colonies of such species as Varroa spp., Nosema spp., PaenibacilIus larvae (American foulbrood), Melissococcus pluton (European foulbrood), and $A$. apis (Shin et al., 2016).

$A$. apis is a fungus spread by bees when they collect pollen and nectar from the plants they visit and transport spores to the hives and infect larvae when nurse bees feed them (Aronstein \& Murray, 2010). The entomopathogen $A$. apis causes chalk brood, a disease which manifests in high humidity conditions and temperatures below $30^{\circ} \mathrm{C}$, which increase the pathogenicity of the fungus (Borum \& Ulgen, 2008). Sex spores (ascospores) are the main cause of infection for 3- and 4-day-old bee larvae because they remain viable for years (Aronstein \& Murray, 2010; Albo et al., 2017). When they are ingested along with the food supplied by the nurse bees, they germinate and pass through the intestinal wall of the larvae, spread throughout the body, appear on the surface when the larva reaches the prepupal stage, and then the fruiting bodies (sporocysts) develop and produce a new generation of ascospores (Bailey, 1981; Jensen et al., 2013; Maxfield-Taylor et al., 2015). The spores pass through the intestine due to the coordinated production of extracellular enzymes, which аге secreted into the environment together with the mechanical pressure of the hyphae in the exoskeleton and/or the peritrophic membrane of the intestine (Wang \& Granados, 2000; Teerayut \& Panuwan, 2008; Cornman et 
al., 2012).

Although the Ascosphaera species are spread throughout the hive by larva cells and feces within the brood nest (Albo et al., 2017), pollen reservoirs are known to contribute to the distribution of ascospores (Wynns et al., 2013; Pereira et al., 2019). Many winter beekeepers feed their hives commercial pollen and sugar syrup to strengthen their colonies after the season (Ahmed, 2008). Pathogens and parasites are transmitted with contaminated pollen among hives and cause serious damage to apiaries not previously exposed to them.

The fungus spores are known to be viable for about fifteen years; they are transported in the pollen brought by the foraging bees to the colony, causing greater risk to the brood (Flores et al., 2005; Lopes et al., 2015). Furthermore, pollen bread and preserved pollen were reported to be reservoirs of entomopathogenic spores, which remain viable for months (Menapace, 1980; Hale Wang \& Granados, 2000). Ascospores of Spanish strains remain viable in commercial pollen after two years of conservation (Tejerina et al., 2019). Larvae are the most susceptible between the fourth and fifth days of age, although some authors argue that this happens between the second and fourth days before the cells are sealed. Therefore, larvae must have consumed A. apis spores for the disease to start (Flores et al., 1996; Jensen et al., 2013; Getachew et al., 2018).

This disease not only affects the larvae of worker bees but also those of drones and queens (Wynns, 2012). While it has not been proven to affect adult bees, they would transmit the disease among hives. Twenty-four hours after the larvae have ingested the ascospores, the first signs of the disease appear, starting with a reduction in the diet (food consumption). The larvae die within $48 \mathrm{~h}$, and fungal mycelia become visible on the surface of the larvae after 72 h (Aronstein \& Murray, 2010). Enzyme machinery involved in the virulence of $A$. apis or genes involved in toxin biosynthesis could act as virulence factors helping the pathogen in the invasion of the host (Cornman et al., 2012; Getachew et al., 2018). Thus, $A$. mellifera bees have developed physical and biological defense mechanisms against pathogens, including the secretion of antimicrobial peptides, phagocytosis, melanization, enzymatic degradation of pathogens (Evans et al., 2006). The physical barriers involved in the defense against pathogens are associated with the intestinal environment of the insect what acts as a filter for microorganisms seeking access to the epithelial cells of the midgut (Siva-Jothy et al., 2005; Lundgren \& Jurat-Fuentes, 2012).

Although entomopathogenic strains have been registered in such countries as the United States, Spain, New Zealand, Australia and Canada (Albo \& Reynaldi, 2010). They have been reported in southern Argentina (Reynaldi et al., 2003; Reynaldi et al., 2015) and the neighboring countries of Chile (Reynaldi et al., 2003), Brazil (Castagnino et al., 2006) and Uruguay (Rivas \& Bettucci, 2007), but there have been no reports for northern Argentina. We investigated pollen from Argentinian provinces because it is available on the local market and many producers use commercial pollen to feed their bee colonies in winter.

The objective of this work was to isolate, identify, and characterize the $A$. apis strains of commercial pollen grains from different Argentinian provinces and their potential pathogenicity in local bees.

\section{MATERIAL AND METHODS}

\section{Isolation of $A$. apis}

Commercial pollen was obtained dried in 2014, 2015 and 2016; one random sample from each province was acquired from herbalists from the Argentinian provinces of Buenos Aires, Corrientes, Entre Ríos, Jujuy, Misiones, San Luis, Santa Fe and Tucumán (Fig. 1). Although the treatment that each sample received is not known, the norms for commercialization proposed by the National Administration of Drugs, Food and Medical Technology had to be followed, which guarantees that Argentinian products are effective, safe and of good quality. The eight samples received from herbalists were stored at $20^{\circ} \mathrm{C}$ in the dark until they 


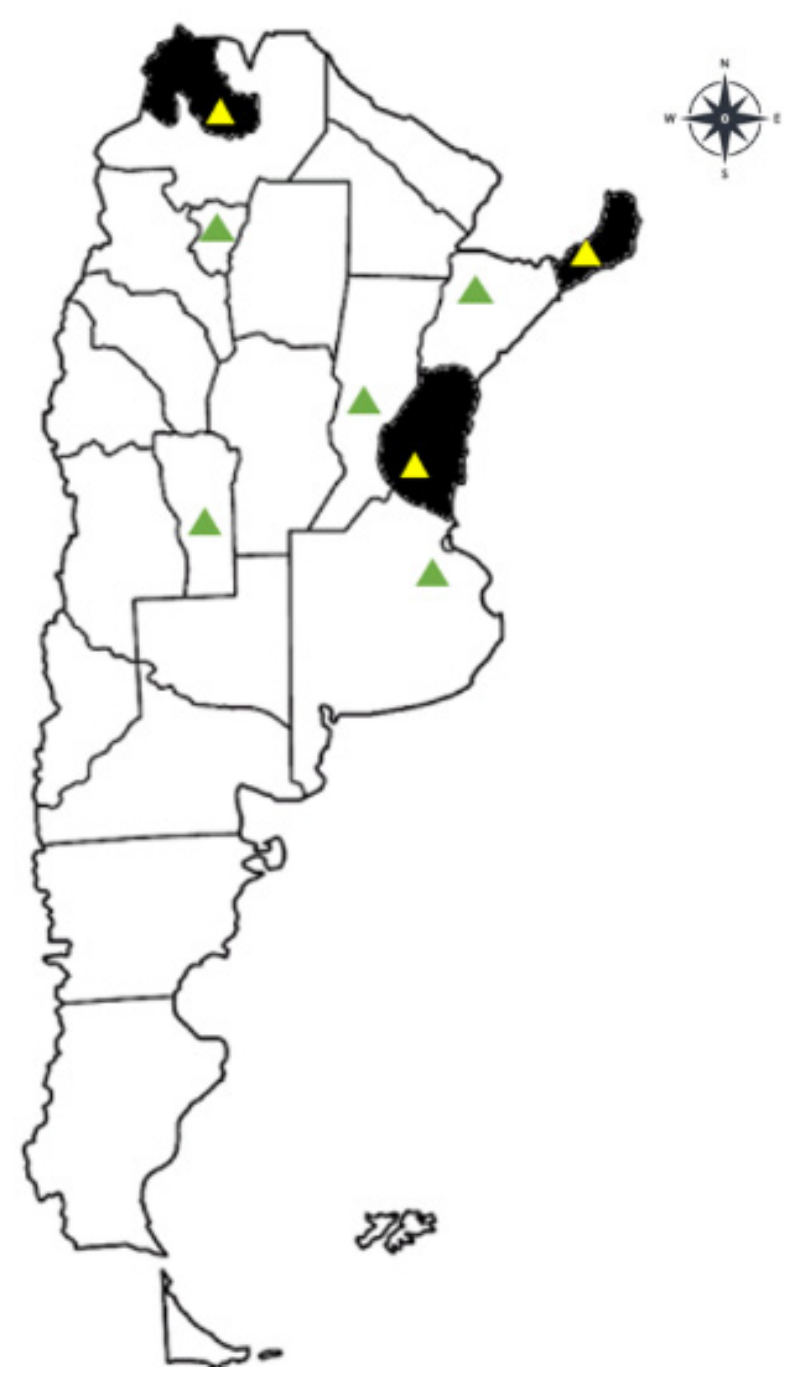

Fig. 1. Distribution of pollen samples collected from apiaries in Argentinian provinces. The yellow triangles denote the isolated samples of $A$. apis, while the green triangles denote the provinces where the samplings were carried out but the fungus $A$. apis was not isolated.

were processed in the laboratory. Then, $1 \mathrm{~g}$ of each pollen sample was seeded on a selective medium containing agar malt and yeast extracts with 20\% glucose (hereafter MY20) (Takatori \& Tanaka, 1982) and incubated under microaerophilia conditions at $30 \pm 2^{\circ} \mathrm{C}$ for fourteen days.

\section{Characterization of the isolated strains}

The fungal strains were selected according to their macroscopic characteristics in the MY20 culture medium. The shape, size and color of the colony as well as the microscopic features, namely shape and size of sporocysts, asci, and ascospores $(\mu \mathrm{m})$ were taken into account. The samples were prepared with lactophenol blue and observed at 40X and 100X under a Zeiss microscope; 1000 sporoscysts and the average size of asci and ascospores were measured $(\mu \mathrm{m})$.

Analysis and identification of $A$. apis strains Genomic DNA was obtained from the collected samples, using the mycelium grown in MY20 liquid medium. The mycelium was washed twice with $1 \mathrm{~mL}$ of cold solution (Tris-HCl 0.1M, EDTA $0.02 \mathrm{M}$ ) and spun at 12,000 rpm for $3 \mathrm{~min}$. Subsequently, the mycelium was crushed with a sterile glass rod in the presence of $1 \mathrm{~mL}$ of extraction buffer (Tris- $\mathrm{HCl} 100 \mathrm{mM} \mathrm{pH} 8, \mathrm{NaCl}$ $1.5 \mathrm{M}$, EDTA $50 \mathrm{mM} \mathrm{pH} 8$, Proteinase $\mathrm{K}, 0.1 \mathrm{mg} /$ $\mathrm{ml}, \beta$-mercaptoethanol $10 \mathrm{mM}$, SDS 2\%) and digested at $60^{\circ} \mathrm{C}$ by agitation with vortex every $10 \mathrm{~min}$. The DNA was purified from the supernatant of this digestion using chloroform:isoamyl alcohol (24:1) twice and potassium acetate 3M only once. The DNA was subsequently precipitated with $100 \%$ isopropanol, $70 \%$ cold ethanol wash, spun at 12,000 rpm for 5 min, dried at room temperature, resuspended in distilled nuclease-free water and stored at $-20^{\circ} \mathrm{C}$ until use. Genomic DNA was revealed in agarose gel at $1 \%$, with $3 \mu \mathrm{L}$ of ethidium bromide $(0.008 \mathrm{mg} /$ $\mu \mathrm{L})$ for every $75 \mathrm{~mL}$ of agarose solution.

Amplification and sequence of analysis of the internal transcribed spacer (ITS) region

To characterize the fungal isolates, the ITS15.8S-ITS2 region of the ribosomal DNA was amplified using the primers described by White et al. (1990), ITS1 5'-TCCGTAGGTGAACCTGCGG and ITS4 5'-TCCTCCGCTTATTGATATGC. The PCR was carried out in $20 \mu$ l of the final volume containing $1 \mathrm{X}$ buffer, magnesium chloride 2.5 mM, dNTPs $200 \mu \mathrm{M}, 10 \rho \mathrm{M}$ of each primer and 0.5 U Taq polymerase, using a cycle composed of an initial denaturation for 4 min at $94^{\circ} \mathrm{C}$ and thirty-five cycles of $40 \mathrm{~s}$ at $94^{\circ} \mathrm{C}, 40 \mathrm{~s}$ at $52^{\circ} \mathrm{C}$, and $40 \mathrm{~s}$ at $72^{\circ} \mathrm{C}$, with a final extension of 10 $\min$ at $72^{\circ} \mathrm{C}$.

The PCR products were checked on agarose gels at $2 \%$, sequenced using the Macrogen Korea service and analyzed with the MEGA6 program. The sequences were contrasted against the 
database of the NCBI (http://www.ncbi.nlm.nih. gov/) using the BLASTn tool. The sequences were checked and corrected before being deposited in the GenBank database

\section{Determination of the phylogenetic relation- ships of the strains}

All sequences were analyzed using BioEdit and Clustal W before tree construction. A phylogenetic analysis was carried out using the program TNT (tree analysis using New Technology), which performs phylogenetic analysis of parsimony (Goloboff et al., 1999). The gaps (indels) were treated as a fifth state since they represented insertion-deletion events. The analysis included twenty-four sequences of the genus Ascosphaera spp. Aspergillus flavus (NG_055742) was used as an outgroup. The data set was reduced in the heuristic search by implementing 100RAS and guarding a tree by TBR. To evaluate the support in identifying groups, we conducted bootstrap and jackknife parsimony analyses. Both analyses included 1000 resampled matrices. For each resampled matrix, we performed one hundred RAS-TBR cycles (Fonseca et al., 2016).

\section{Palynological analysis}

Argentinian samples of corbicular pollen were disintegrated and homogenized with a mortar and $0.5 \mathrm{~g}$ of the total was taken for additional treatment with acetolysis (Erdtman, 1960). The pellet was glycerin mounted and paraffin sealed. Observations were made with a Boeco optical microscope. To determine frequency classes, 600 pollen grains were counted (Louveaux et al., 1978). Pollen types were compared and identified to the palynological deposits from the palynology laboratory of the Faculty of Agrarian Sciences, National University of Jujuy, and by consulting the palynological atlas.

\section{Pathogenicity assay \\ Bees and apiary}

The bees used to carry out the assays belong to the hybrid subspecies $A$. m. scutellata, present in the province of Jujuy, Argentina, as reported by Porrini et al. (2020) in this region.
The bees used for the assay were maintained in Langstroth hives on an experimental farm in Severino (Faculty of Agrarian Sciences of the National University of Jujuy), located in El Carmen department, Jujuy province.

\section{Assay preparation}

We used three blind cores (no initiating queen), that had been prepared in the spring of 2016 and contained a standard open breeding frame, a breeding frame operculated with nurse bees and a frame with honey, as proposed by Ahmed (2008). We waited until the birth and posture of the queen. When the nuclei grew and consolidated, with about 10,000 bees per frame, they were transferred to three standard brood boxes and allowed to grow again until we obtained a population of approximately 50,000 bees, as proposed by Audisio \& Benítez-Ahrendts (2011). Above this brood nest, we placed a medium super frame (without a queen excluder, to allow the queen to pass), which contained twentyfour experimental frames specially designed for assays, measuring $20 \times 10 \mathrm{~cm}$. When the worker bees stretched the beeswax, the posture of the queen was observed, and then when the first bees were born, the state of the hives was monitored monthly. Trials were conducted in the late spring of 2017 and 2018 when temperatures were below $20^{\circ} \mathrm{C}$, the morning temperature registered in this season in Jujuy province. The three hives used for the study were eliminated at the end of the trial to prevent the spread of the disease.

\section{Activation of $A$. apis}

Portions of each fungal strain inoculated with agar and mycelium (about $36 \mathrm{~mm}^{2}$ ) were placed on Petri dishes in the middle of the MY20 culture and the fungi were grown for ten days until the maturation of sporocysts, under microaerophilia conditions at $30 \pm 1^{\circ} \mathrm{C}$. Microscopic observation was performed to confirm the presence of mature spores with a $40 \mathrm{X}$ objective.

\section{Preparation of the inoculum}

An aliquot was taken from each $A$. apis strain and suspensions were made in tubes with $5 \mathrm{~mL}$ 
of sterile water-peptone (10 g of peptone, $5 \mathrm{~g}$ of sodium chloride in 1 liter of distilled water). To release the asci and ascospores contained in the sporocysts, each tube containing glass beads was vortexed for thirty seconds. Counts were performed using a Neubauer chamber, with the concentration adjusted between $5 \times 10^{3}$ spores/ $\mathrm{mL}$ (minimum) and $5 \times 10^{6}$ spores/mL (maximum). These suspensions were kept at $5^{\circ} \mathrm{C}$ until their administration (Jensen et al., 2013; Ansari et al., 2017).

Before being administered to the hives, the ascospore suspensions were spun at 4000 rpm for $5 \mathrm{~min}$ and the cell pellets were resuspended in $5 \mathrm{~mL}$ of sterile water and honey (1:1). For the control groups (without ascospores), a suspension of $5 \mathrm{~mL}$ of sterile water and honey was used (1:1).

Selection and feeding of larvae with ascospores

The brood chambers of the three assayed colonies were checked before the administration of the ascospores and showed no symptoms or signs of the disease. The uniform posture of the queen and the presence of larvae were verified. Ten open breeding trial frames containing 5- to 6-day-old larvae were selected for the inoculation of the fungal strains. Two repetitions per area of $20 \times 10 \mathrm{~cm}$ were performed and areas with capped and uncapped cells were counted before the administration of the strains.

Subsequently, all larvae were fed using a sterile $2.5 \mathrm{~mL}$ syringe. They were divided into three groups; the first two were administered a drop of approximately $5 \mu \mathrm{L}$ of each ascospore suspension at different concentrations: at the minimum concentration and the maximum concentration, respectively, while the third group was used as control (food without ascospores) (See Tab. 3). After feeding, the frames were taken to the original hive so that the cells could be covered by worker bees. At $48 \mathrm{~h}$, the frames were removed from the apiary and incubated in the laboratory for ten days in hives designed for the frames. The mummified larvae in each cell were then counted. To replicate the humidity and temperature environmental conditions in the laboratory, we used a stove at $30 \pm 1^{\circ} \mathrm{C}$ with $60 \%$ humidity.

\section{Statistical analysis}

Data on the number of infected larvae were expressed as mean \pm standard deviation of each assay. Statistical analysis of results was performed using ANOVA and Tukey's mean comparison test, with a 0.5 probability of making a type I error, using Infostat as the statistical package (Di Rienzo et al., 2008).

\section{RESULTS}

Isolation and characterization of $A$. apis. strains

Three strains of the genus $A$. apis were isolated from pollen grains of the provinces of Jujuy, Misiones, and Entre Rios, Argentina. They were identified by their macro and microscopic characteristics (Tab. 1, Fig. 2). The development of the sporocysts was observed at five days of incubation. The mycelium exhibited a white cottony, aerial, mostly bright consistency, and its hyphae were covered with droplets of "exudate". When the asci ripened, they looked

Macroscopic description of isolated Ascosphaera spp. strains

Table 1.

\begin{tabular}{cccccc}
\hline Ascosphaera spp. & strains & Origins & $\begin{array}{c}\text { Sporocyst } \\
\text { diameter } \\
(\mu \mathrm{m})\end{array}$ & $\begin{array}{c}\text { Ascus diameter } \\
\text { average }(\mu \mathrm{m})\end{array}$ & $\begin{array}{c}\text { Ascospores length } \\
\text { average }(\mu \mathrm{m})\end{array}$ \\
\hline A. apis & PMis & Misiones & $60-75$ & 9 & $1-2$ \\
A. apis & PJuy & Jujuy & $65-70$ & 9 & $1-2$ \\
A. apis & PER & Entre Ríos & $60-70$ & 8 & $1-2$ \\
\hline
\end{tabular}




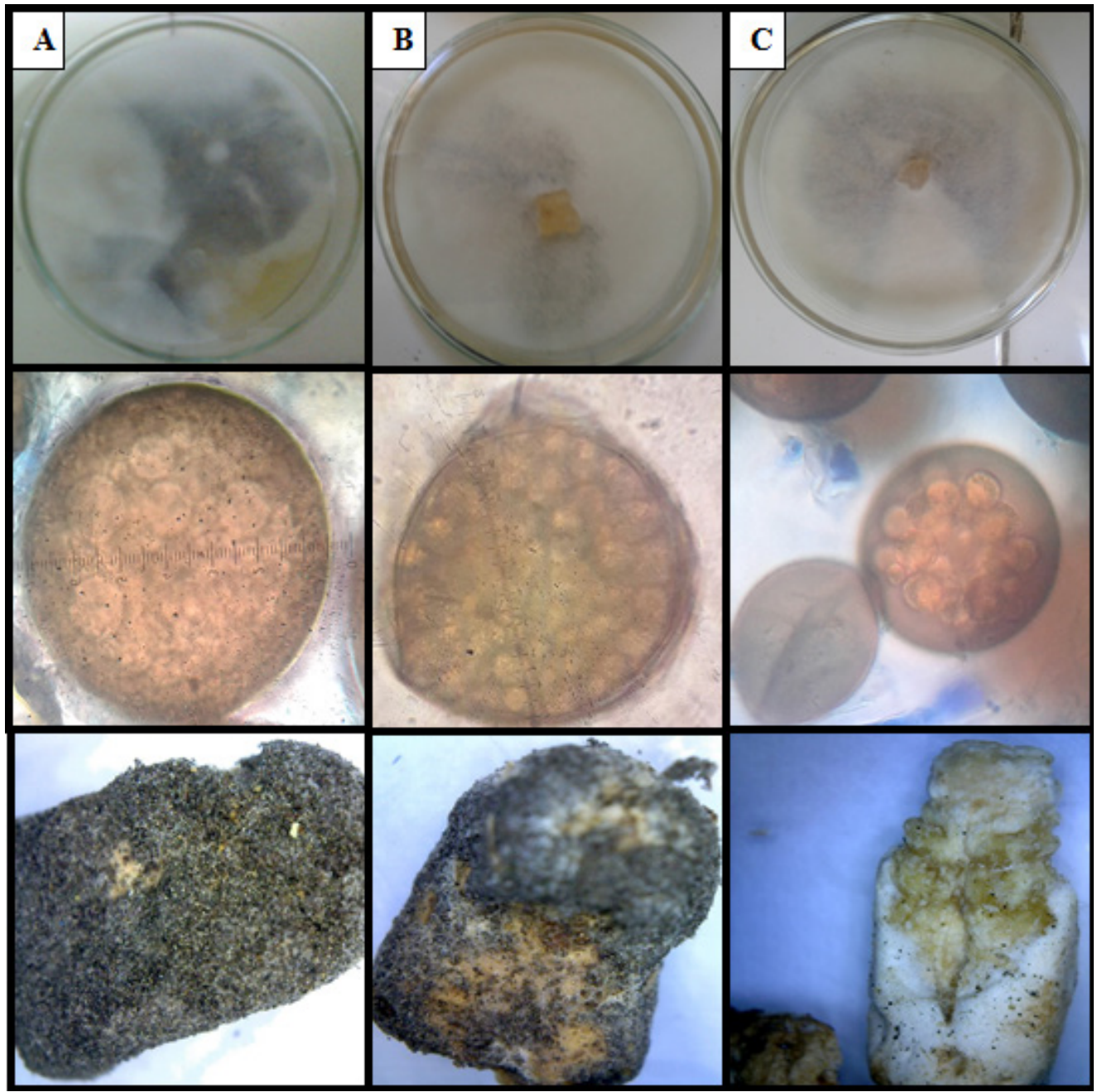

Fig. 2. Macroscopic and microscopic observation in MY20 culture medium.

A) Growth and sporulation of $A$. apis strain PMIS (Misiones), sporocyst observed at $100 \mathrm{X}$ and mummified larvae observed at $10 \mathrm{X}$.

B) Growth and sporulation of $A$. apis strain PJUY (Jujuy), sporocyst observed at $100 \mathrm{X}$ and mummified larvae observed at 10X.

C) Growth and sporulation of $A$. apis strain PER (Entre Ríos), sporocyst observed at 40X and mummified larvae observed at 10X (without sporocyst).

black. We observed microscopic spherical brown sporocysts, containing globose asci whose ascospores were hyaline and ellipsoid. The provinces of Tucumán, Buenos Aires, San Luis, Corrientes and Santa Fe had not registered the presence of $A$. apis in commercial pollen, but strains belonging to the genera Aspergillus, Fusarium, Penicillium, Rhizopus and Mucor were isolated and identified.

Molecular identification of $A$. apis strains and registration of their botanical origin

The $A$. apis strains corresponding to the three provinces yielded polymorphic fragments of 304bp for the Misiones strain, 482bp for Entre
Ríos, and 610bp for Jujuy, and shared 100\%, $98.3 \%$, and $99.02 \%$ identity, respectively, with other strains from the NCBI database. They were registered with the following access numbers: MH633694 (Misiones), MH633695 (Entre Ríos), and MH633693 (Jujuy).

In addition, when the botanical origin of each pollen sample was identified, interestingly, the predominant pollen belonged to the genus Rapistrum and the family Amaranthaceae. While the species Helianthus annus was only recorded in the pollen of Entre Ríos and Misiones, a large percentage of pollen from Jujuy corresponded to the family Myrtaceae (Tab. 2, Fig. 3). 
Table 2.

Botanical origin associated with the three strains of Ascosphaera apis isolated from commercial pollen in Argentina

\begin{tabular}{|c|c|c|c|}
\hline \multirow{2}{*}{ Pollen types } & \multicolumn{3}{|c|}{ Porcentage by provincie } \\
\hline & Entre Ríos & Jujuy & Misiones \\
\hline Amaranthaceae & 8.87 & 6.42 & 12.05 \\
\hline Apiaceae & 0.55 & 0.28 & 0 \\
\hline Caesalpiniaceae & 0.92 & 0 & 0 \\
\hline Carduus & 1.11 & 0 & 0.17 \\
\hline Fabaceae & 0 & 1.4 & 0 \\
\hline Helianthus annuus & 14.23 & 0 & 18.59 \\
\hline Juglans & 0 & 0.56 & 0 \\
\hline Monocotyledoneae & 0.74 & 0 & 1.55 \\
\hline Myrtaceae & 0 & 97.6 & 0 \\
\hline Peltophorum dubium & 0 & 1.96 & 0 \\
\hline Poaceae & 0 & 0 & 0.34 \\
\hline Zea mays & 2.22 & 1.4 & 1.38 \\
\hline Tithonia & 0 & 5.31 & 0 \\
\hline Rapistrum & 68.58 & 73.18 & 61.96 \\
\hline Salix & 0 & 0 & 0.34 \\
\hline Sapium haematospermum & 1.66 & 3.07 & 1.72 \\
\hline Senecio & 0 & 3.91 & 0 \\
\hline Solanaceae & 0.55 & 1.12 & 0.69 \\
\hline Taraxacum officinale & 0.55 & 1.4 & 0.52 \\
\hline
\end{tabular}

\section{Phylogenetic relationships}

A total of 872 bp were aligned, 299 sites were considered monomorphic, 504 sites were considered polymorphic or phylogenetically informative segregants, and 359 polymorphic sites had more than two variants. The parsimony analysis resulted in two parsimonious trees, with 1889 steps.

Ascosphaera spp. strains were grouped into different phylogenetically related groups. Thus, all $A$. atrastrains shared a common ancestor with
$100 \%$ support in the bootstrap and jackknife processes. The $A$. atra and $A$. duoformis strains also shared a common ancestor with the species $A$. subcuticulata, $A$. solina, and $A$. osmophila with $75 \%$ jackknife support and $70 \%$ bootstrap support (Fig. 4).

The $A$. apis strain and other species of the Ascosphaera genus have a common ancestor with $100 \%$ jackknife support, while for the bootstrap process it is located next to the strains of Russia, Australia, the United States and all other 


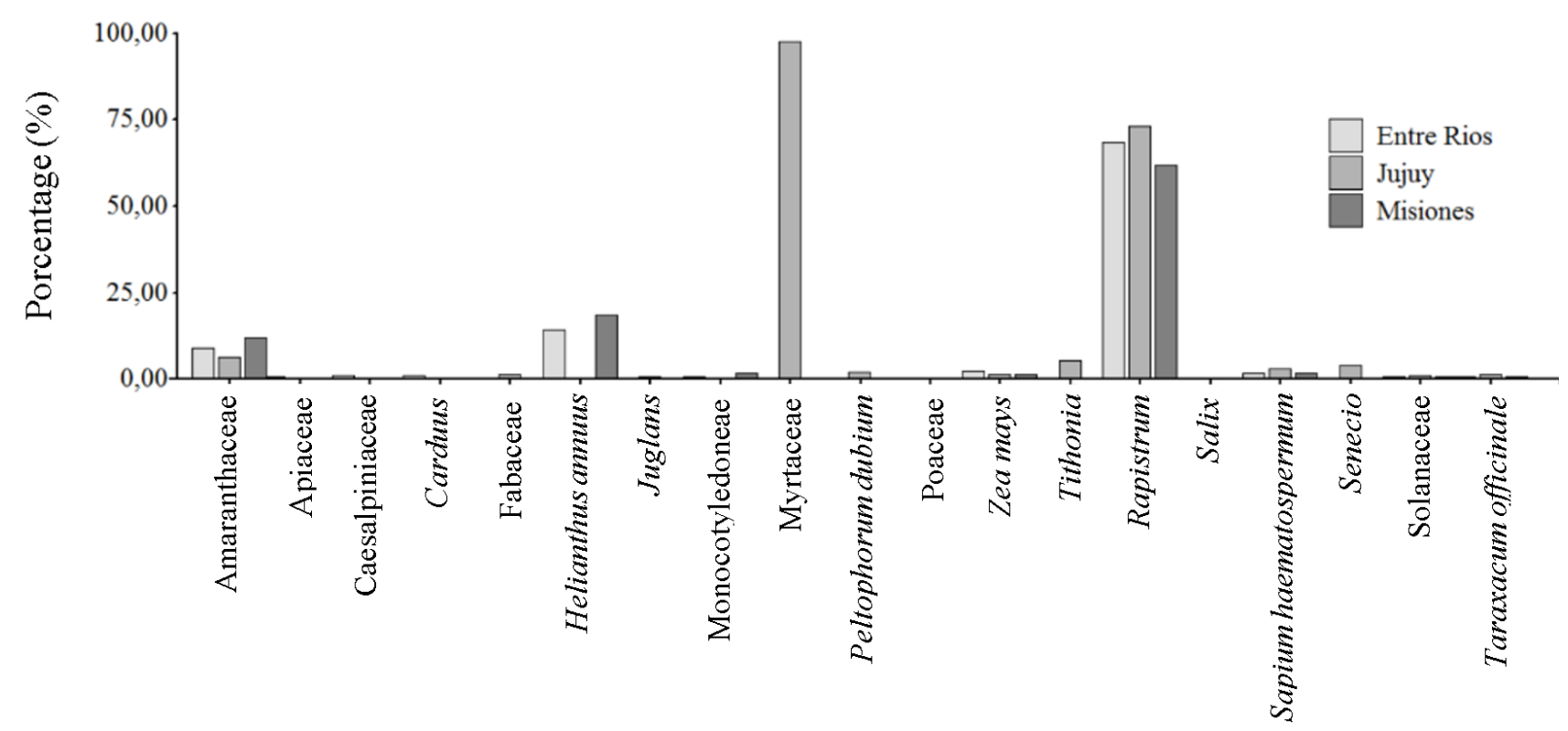

Fig. 3. Percentage of pollen containing $A$. apis.

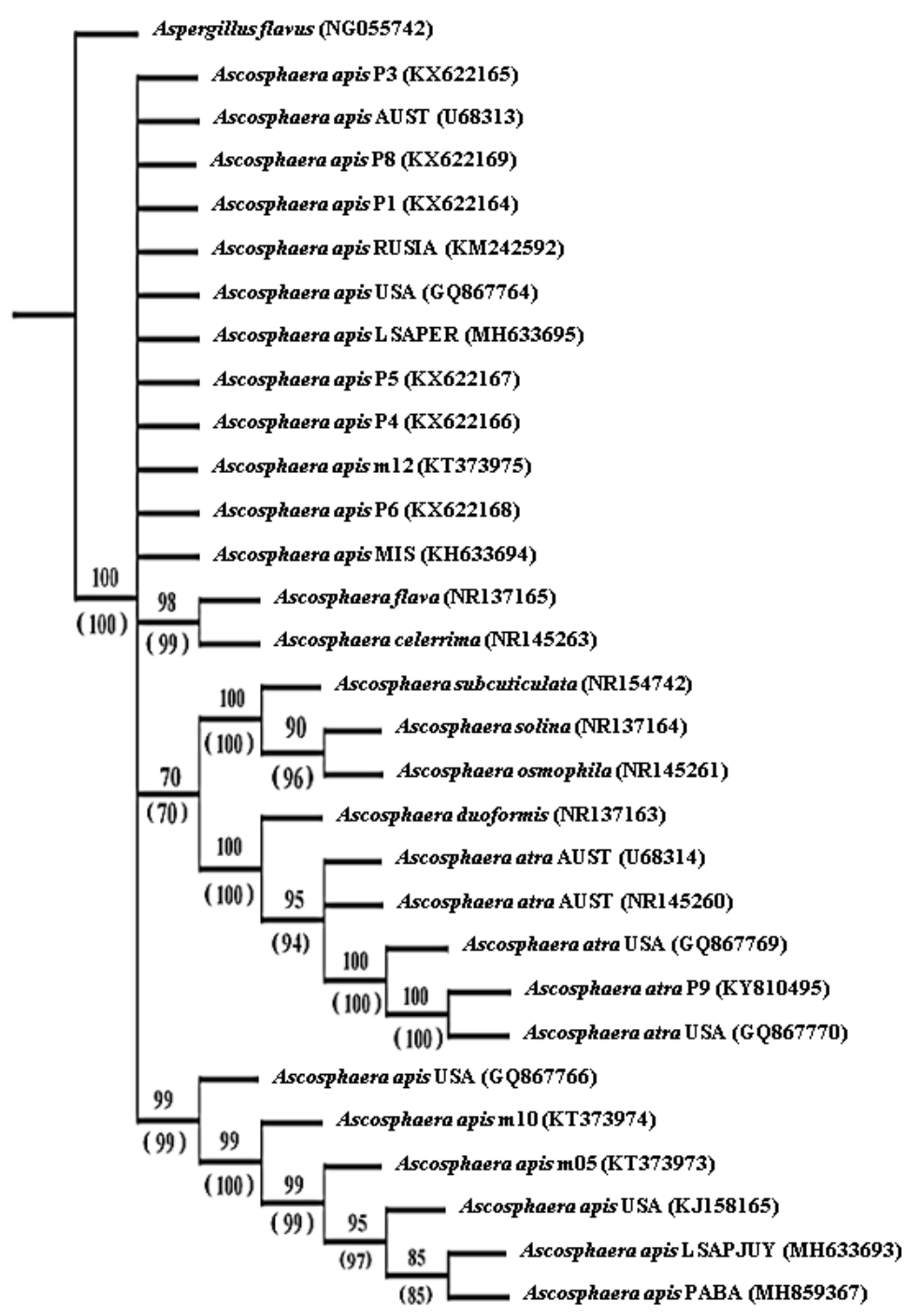

Fig. 4. Phylogenetic relationship of $A$. apis strains. The tree was carried out using 1000 replications and bootstrap and jackknife parsimony. The numbers in parentheses correspond to the jackknife support. 
Spanish strains. This group contains the strains from Entre Ríos and Misiones. By contrast, the strain from Jujuy belongs to another monophyletic group with strains from the Netherlands and share an immediate common ancestor with those of the United States and the Spanish strains $A$. apis M05 and M10. Furthermore, the $A$. celerrima and $A$. flava strains formed a monophyletic group with similar supports separating from the species of $A$. apis and $A$. atra (Fig. 4).

\section{Pathogenicity assays}

The minimum concentration of ascospores administered in sugar syrup did not differ sig- centages close to $11 \%$, while those from Jujuy and Misiones registered infection values close to $27 \%$ and $23 \%$, respectively (Tab. 3). The strains from Misiones and Entre Ríos produced 2\% of mummified larvae without sporocysts (white mummies), while the strain from Jujuy caused $6 \%$. Closed cells previously capped by bees were not significant for the trial.

The larvae inoculated with $A$. apis strains were mummified between days 7 and 10 of incubation. The size of the mummified larvae of worker bees was between $7.5 \mathrm{~mm}$ and $8 \mathrm{~mm}$, while that of drones was between 11 and 13 $\mathrm{mm}$ (Fig. 2).

Number of larvae mummies with $A$. apis and no mummies.

Table 3.

Values are mean \pm standard deviation

\begin{tabular}{|c|c|c|c|c|c|c|c|}
\hline \multirow[b]{2}{*}{ Strains } & \multicolumn{3}{|c|}{ Number of mummies } & \multirow{2}{*}{$\begin{array}{l}\text { Number of } \\
\text { non-mummi- } \\
\text { fied larvae } \\
\text { (Witness) }\end{array}$} & \multirow{2}{*}{$\begin{array}{c}\text { Number of } \\
\text { infected larvae } \\
\left(5 \times 10^{3}\right. \\
\text { spores } / \mathrm{mL})\end{array}$} & \multirow{2}{*}{$\begin{array}{l}\text { Number of } \\
\text { infected } \\
\text { larvae } \\
\left(5 \times 10^{6}\right. \\
\text { spores/mL) }\end{array}$} & \multirow{2}{*}{$\begin{array}{c}\text { Total } \\
\text { number } \\
\text { of capped } \\
\text { cells }\end{array}$} \\
\hline & $\begin{array}{c}\left(5 \times 10^{3}\right. \\
\text { spores/ } \\
\mathrm{mL})\end{array}$ & $\begin{array}{c}\left(5 \times 10^{6}\right. \\
\text { spores/ } \\
\mathrm{mL})\end{array}$ & $\begin{array}{l}\text { Without } \\
\text { sporocyst }\end{array}$ & & & & \\
\hline Misiones & 0 & $30 \pm 7$ & $3 \pm 3$ & $100 \pm 40$ & $138 \pm 1$ & $127 \pm 29$ & $43 \pm 6$ \\
\hline Entre Ríos & 0 & $10 \pm 1$ & $2 \pm 2$ & $112 \pm 2$ & $128 \pm 12$ & $83 \pm 9$ & $28 \pm 11$ \\
\hline Jujuy & $1 \pm 1$ & $23 \pm 3$ & $5 \pm 1$ & $102 \pm 32$ & $134 \pm 10$ & $85 \pm 43$ & $54 \pm 8$ \\
\hline
\end{tabular}

nificantly (ANOVA, $p=0.83$ ) in the number of mummified larvae. No mummified larvae were detected in connection with the Entre Rios or Misiones strains, and only the Jujuy strain showed the presence of $1 \pm 1$ mummified larva (Tab. 3). In contrast, when the suspension with the maximum concentration of ascospores was administered to the larvae, the registered number of mummified larvae with each of the fungal strains was higher (Misiones $30 \pm 7$, Entre Rios $10 \pm 1$ and Jujuy $23 \pm 3$ ) than the number of mummified larvae fed the minimum concentration of ascospores (Tab. 3). The number of mummified larvae with high concentrations of ascospores exhibited significant differences between the pathogenic effects of the strains from each province (ANOVA, $\mathrm{p}<0.05$ ) (Fig. 5). The $A$. apis strain from Entre Rios affected the lowest number of mummified larvae, with per-

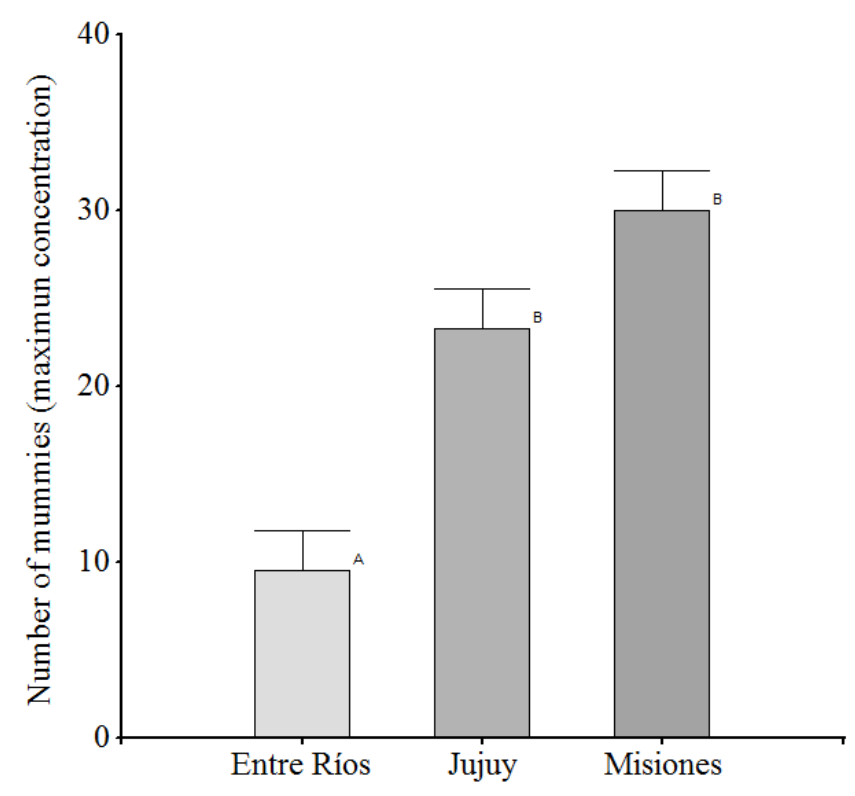

Fig. 5. Record of larvae mummied with $A$. apis. Values are mean \pm standard deviation. Different letters represent differences between strains $(p<0.05)$. 


\section{DISCUSSION}

In this study, we isolated strains belonging to the genus Ascophaera from commercial pollen of three Argentinian provinces, where local circulation of the fungal strain identified as $A$. apis had not been reported. The presence of the entomopathogen was also recorded in commercial pollen of Spanish provinces, where the presence of this fungus had been reported before (Tejerina et al., 2019). In other studies, Ascosphaera spp. has been isolated from $A$. mellifera larvae, Apis cerana, Xylocopa californica arizonensis, and adult bumblebees (Reynaldi et al., 2015; Chen et al., 2018). The presence of A. apis has also been reported in honey samples from the province of Buenos Aires, Argentina (Reynaldi et al., 2003), but this province yielded negative results for the pollen sample analyzed in this study.

Commercial pollen subjected to different treatments after harvesting, in which it is dried at temperatures below $40-45^{\circ} \mathrm{C}$, eliminates excess humidity (6 to $7 \%$ ) and preserves the bromatological characteristics required for its commercialization (Aranda-Escribano et al., 1999; Baldi-Coronel et al., 2004). Although these treatments eliminate most of the microorganisms, an incorrect procedure could transport diseases to the bee colonies, as demonstrated by Graystock et al. (2016), who recorded the presence of Ascosphaera spp., Nosema spp., among others, in pollen with different treatments. Similarly, Zuluaga et al. (2015) recorded the presence of $10^{5} \mathrm{UFC} / \mathrm{gr}$ of filamentous fungi and yeasts in commercial pollen but did not report the genus found. In the provinces where the presence of $A$. apis had not been previously recorded, we found strains belonging to different genera, as also recorded by BucioVillalobos et al. (2010), who observed different percentages of the genus in commercial pollen: Aspergillus (3.6\%), Alternaria (3.6\%), Mucor (3.1\%), Fusarium (2.9\%), Penicillium (2.9\%) and Rhizopus (0.7\%). These authors attributed their findings to a deficiency in the drying and conservation processes of pollen, although they did not report the presence of Ascosphaera spp.
Therefore, the presence of Ascosphaera spp. strains could be explained as a deficiency in the treatment of the collected pollen.

The morphological observation indicated that the size of the strains' sporocysts and the ascospores were similar to those reported in other works from both southern Argentina and other parts of the world (Albo \& Reynaldi, 2010; Aronstein \& Murray, 2010; Wynns et al., 2013; Chen et al., 2018; Pereira et al., 2019). The phylogenetic analysis allowed us to establish relationships between strains found in some countries and isolates of commercial pollen from Argentina. The $A$. apis strains from pollen grains from the provinces of Misiones and Entre Ríos were grouped together, while the strain isolated from pollen grains from Jujuy was placed in another group, evidencing polymorphic variations within the group of Argentina. This intraspecific variation was also observed by Jensen et al. (2012), who described twelve polymorphic variants of $A$. apis in Denmark and the United States. In the same way, Tejerina et al. (2019) showed that Spanish strains are grouped in a monophyletic clade and phylogenetically move away from other strains. In this study, we compared Ascosphaera spp. isolated from pollen grains in some countries, checking for genetic variation between regions.

Although multifloral pollen is known to contain ascospores (Pereira et al., 2019), the palynological origin associated with its transmission has not been determined. In this work, botanical determinations of pollen grains from Argentinian provinces are reported to corroborate their provenance. In addition, the most representative percentages of each floral resource used by $A$. mellifera in its diet are reported, with the genus Rapistrum, the families Myrtaceae and Amaranthaceae, and the species Helianthus annus being found in higher proportions in the three provinces, coinciding with Burgos \& Sánchez (2015) and Méndez et al. (2018) (Jujuy), Aquino et al. (2015) (Misiones), and Ciappini \& Vitelleschi (2013) (Entre Ríos). The reported plant groups could be reservoirs of the fungal strains found, but more research is needed for confirmation. Our pathogenicity assays of the different 
strains in bee larvae allowed us to assess their potential to infect and mummify larvae of local bees that have never been exposed to this entomopathogen. Flores et al. (2004) evaluated the percentage of mummified larvae that were stressed at $18^{\circ} \mathrm{C}$ for $24 \mathrm{~h}$. These larvae came from hives which were treated with water spray with ascospores, pollen with ascospores or sugar syrup containing the ascospores; the third technique was the least effective in achieving a pathogenic effect. These assays were performed with a concentration of 1,250 spores/hives. In this work, a concentration of $5 \times 10^{6}$ spores $/ \mathrm{mL}$ was used and the percentage of mummies was lower than that found by flores et al. (2004) and Palacios et al. (2007), when they used sugar syrup. Both authors warned that the percentage of mummification depends on the stress conditions of the larvae when they receive the ascospores or on their susceptibility to contract the ectoparasite according to the period of the year.

The administration of the minimum concentration of ascospores to the larvae did not result in the disease. Jensen et al. (2013) indicated that the minimum concentration for successful infection in healthy hosts should be $5 \times 10^{5}$ ascospores $/ \mathrm{mL}$, which could lead to the death of the population. The pathogenicity also depends on the origin of the inoculum with ascospores. Flores et al. (2004) performed the infection techniques with ascospores from macerated bee mummies, while Palacios et al. (2007) maintained ascospores on integral rice kernels (IRK) medium and MY20. The lower percentages of infection of the larvae achieved by the direct method of feeding than those obtained in other works could be attributed to the ascospores coming from the cultivation of commercial pollen.

In addition, this low percentage of mummified larvae in comparison to other studies can also be attributed to the genetic characteristics of the bee colonies kept in Jujuy, since hybrids of Africanized bees belonging to the subspecies of $A$. m. scutellata have been reported to be present in this region, as shown by Porrini et al. (2020). Although few reports have indicated that the subspecies $A$. m. scutellata is susceptible to contracting the disease caused by $A$. apis, this subspecies is known to be more resistant to infestation than other more susceptible European bee subspecies, including the Varroa destructor ectoparasite (Principal et al., 2008; Nganso et al., 2017). The behavior of $A$. apis in other populations of Argentinian bees needs further investigation.

Strains of $A$. apis were isolated and identified from commercial pollen of Argentinian regions, where the prevalence of this entomopathogen had not been recorded, showing that the pollen commercialized in these areas is not treated properly and therefore is a reservoir of different pathogenic fungal strains of bees. The phylogenetic analysis differentiated $A$. apis strains of Misiones and Entre Ríos from those of Jujuy, suggesting genetic variation between regions. The botanical origin of the pollen was found to belong to the mentioned regions, and it indicates that certain pollen resources used by A. mellifera could be reservoirs of fungal strains, including the $A$. apis fungus. The first results were obtained on the pathogenicity of Argentinian fungal strains on larvae.

\section{ACKNOWLEDGMENTS}

Part of the experimental work was funded by Secretaría de Ciencia y Técnica de Estudios Regionales, Universidad Nacional de Jujuy (SeCTER-UNJu) and Consejo Nacional de Investigaciones Científicas y Técnicas (CONICET-Argentina).

\section{REFERENCES}

Ahmed, A.. (2008). Manual Apícola del Norte Argentino. Magna, Tucumán, Argentina.

Albo, G.N., \& Reynaldi, F.. (2010). Ascosphaera apis, agente etiológico de la cría yesificada de las abejas. Revista Argentina de Microbiología, 42(1), 80.

Albo, G., Córdoba, S., Reynaldi, F. (2017). Chalkbrood: pathogenesis and the interaction with honeybee defenses. International Journal of Environmental \& 
Agriculture Research, 3(1), 71-80.

Alonso, J.M., Rey, J., Puerta, F., Hermoso de Mendoza, J., Hermoso de Mendoza, M., Flores, J.M. (1993). Enzymatic equipmet of Ascosphaera apis and the development of infection by this fungus in Apis mellifera. Apidologie, 24(4), 383-390. https://doi.org/10.1051/ apido:19930404

Ansari, M.J., Al-Ghamdi, A., Usmani, S., Khan, K.A., Alqarni. A.S., Kaur, M., Al-Waili, N. (2017). In vitro evaluation of the effects of some plant essential oils on Ascosphaera apis, the causative agent of Chalkbrood disease. Saudi Journal of Biological Sciences, 24(5), 1001-1006. https://doi.org/10.1016/j. sjbs.2016.04.016.

Aquino, D., Pellizzer N., Miranda D., Salgado C. (2015). Contenido polínico de mieles de Apis mellifera L. producidas en Misiones, Argentina. Revista Forestal Yvyraretá, 22, 7-12.

Aranda-Escribano, M.L. Cardenal Galvan, J.A., Álvarez Gomez, J.A., Pozovera, J. (1999). El polen, controles sanitarios. Normas Legales. Vida Apícola (España), 94, 56-59.

Aronstein, K., \& Murray, K. D. (2010). Chalkbrood disease in honey bees. Journal Invertebral Pathololy, 103(1), S20-S29. https://doi.org/10.1016/j. jip.2009.06.018

Aronstein, K., \& Holloway B. (2013). Honey bee fungal pathogen, Ascosphaera apis, current understanding of host-pathogen interactions and host mechanisms of resistance. Microbial Pathogenesis, 13(1), 402-410.

Audisio, M.C., \& Benítez-Ahrendts, M.R. (2011). Lactobacillus johnsonii CRL1647, isolated from Apis mellifera L. bee-gut, exhibited a beneficial effect on honeybee colonies. Beneficial Microbes, 2(1), 29-34. https://doi.org/10.3920/BM2010.0024

Bailey, L. (1981). Honey Bee Pathology. (pp. 40-44) London: Academic Press.

Baldi Coronel, B., Grasso, D., Chaves Pereira, S.,
Fernández, G. (2004). Caracterización bromatológica del polen apícola argentino. Ciencia, Docencia y Tecnología, 15(29), 145-181. Retrieved July 8, 2020, from https://www.redalyc.org/articulo.oa?id=14502906

Borum, A.E., \& Ulgen, M. (2008). Chalkbrood (Ascosphaera apis) infection and fungal agents of honey bees in north-west Turkey. Journal Apicultural Research, 472), 170-171. https://doi.org/10.3896/ ibra.1.47.2.16

Bucio-Villalobos, C.M., López-Preciado, G., Martínez Jaime, O.A., Torres-Morales, J.l. (2010). Micoflora asociada a granos de polen recolectados por abejas domésticas (Apis melliferaL). Nova scientia, 2(4), 93103. https://doi.org/10.21640/ns.v2i4.212

Burgos, M.G., \& Sánchez A.C. (2014). Preferencias alimenticias en las mieles inmaduras de Apis mellifera en el chaco serrano (Jujuy, Argentina). Boletín de la Sociedad Argentina de Botánica, 49(1), 41-50. http:/l dx.doi.org/10.31055/1851.2372.v49.n1.7820

Castagnino, G.L.B., Funari, S.R.C., Blume, E., Arboitte, M.Z., Weber, M. (2006). Doença Cria Giz Ascosphaera apis(Maassenex Claussen) Olive \& Spiltoir emabelhas Apis mellifera L. na Depressão Central do Rio Grande do Sul. Ciência Rural, 36(6), 1909-1911. https://doi. org/10.1590/S0103-84782006000600038

Chen, D., Guo, R., Xiong C., Zheng, Y., Hou, C., Fu Z. (2018). Morphological and molecular identification of chalkbrood disease pathogen Ascosphaera apis in Apis ceranae. Journal of Apicultural Research, 574), 1-6. https://doi.org/10.1080/00218839.2018.14759 43

Ciappini, M.C., \& Vitelleschi, M.S. (2013). Características palinológicas de mieles de eucalipto (Eucalyptus sp.) y tréboles (Trifolium sp.) provenientes de la provincia fitogeográfica pampeana argentina. Revista FCA UNCuyo, 45(1), 247-258.

Cornman R.S., Bennett A.K., Murray K.D., Evans J.D., Elsik C.G., Aronstein, K. (2012). Transcriptome analysis of the honey bee fungal pathogen, Ascosphaera apis. implications for host pathogenesis. BMC Genomics, 13(1), 285, http://doi.org/10.1186/1471- 


\section{J. APRC. SCLI. VOL. 65 NO. 1 2021}

\section{4-13-285}

Di Rienzo, J.A., Casanoves, F., Balzanini, M.G., Gonzalez, L., Tablada, M., Robledo, C.W. (2008). Grupo Infostat, versión 2008, FCA, Univ. Nacional de Córdoba, Argentina.

Erdtman, G. (1960). The acetolysis method, a revised description. Svensk Botanisk Tidskrift. 54, 561-564.

Evans, J.D., Aronstein, K., Chen, Y.P., Hetru, C., Imler,

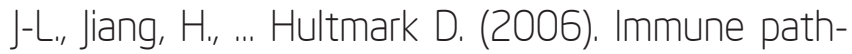
ways and defence mechanisms in honey bees Apis mellifera. Insect Molecular Biology, 15(5), 645-656. https://doi.org/10.1111/j.1365-2583.2006.00682.x

Flores J.M., Gutiérrez I., Puerta F. (2004). A comparison of methods to experimentally induce chalkbrood disease in honey bees. Spanish Journal of Agricultural Research, 2(1), 79-83. https://doi.org/10.5424/ sjar/2004021-63

Flores, J.M., Gutiérrez, I., Espejo R. (2005). The role of pollen in chalkbrood disease in Apis mellifera. transmission and predisposing conditions. Mycologia, 976), 1171-1176. https://doi.org/10.3852/mycologia.97.6.1171

Flores, J.M., Ruiz, J.A., Ruz, J.M., Puerta, F., Busto, M., Padilla, F., Campano, F. (1996). Effect of temperature and humidity of sealed brood on chalkbrood development under controlled conditions. Apidologie, 274), 185-192. https://doi.org/10.1051/apido:19960401

Fonseca, M.I., Tejerina, M.R., Sawostjanik-Afanasiuk, S.S., Giorgio, E.M., Barchuk, M.L., Villalba, L.L., Zapata, P.D. (2016). Preliminary studies of new strains of Trametes sp. from Argentina for laccase production ability. Brazilian Journal of Microbiology, 472), 287297. https://doi.org/10.1016/j.bjm.2016.01.002

Getachew, A., Wubie, A. J., Wu, J., Xu, J., Wu, P., Abejew, T.A., ... Xu, S.F. (2018). Molecular identification of pathogenicity associated genes in honeybee fungal pathogen, Ascosphaera apis, by restricted enzymemediated integration (REMI) constructed mutants. International Journal of Agriculture and Biology, 2012), 2879-2890.
Goloboff, P.A., (1999). Analyzing large data sets in reasonable time: solution for composite optima. Cladistics, 15(4), 415-428, https://doi.org/10.1006/ clad.1999.0122

Graystock, P., Jones, J.C., Pamminger, T., Parkinson, J.F., Norman, V., Blane, E.J., ... Hughes, W.O.H. (2016). Hygienic food to reduce pathogen risk to bumblebees. Journal of Invertebrate Pathology, 136, 68-73. https://dx.doi.org/10.1016/j.jp.2016.03.007

Hale, P.., \& Menapace, D.M. (1980). Effect of time and temperature on the viability of Ascosphaera apis. Journal Invertebral Patholology, 36(3), 429-430. https://doi.org/10.1016/0022-2011(80)90050-6

Holloway, B., Tarver, M.R., Rinderer, T.E. (2013). Fine mapping identifies significantly associating markers for resistance to the honey bee brood fungal disease, chalkbrood. Journal of Apicultural Research, 52(3), 134-140. https://doi.org/10.3896/ibra.1.52.3.04

Jensen, A.B., Aronstein, K., Flores, J.M., Vojvodic, S., Palacio, M.A., Spivak, M. (2013). Standard methods for fungal brood disease research. Journal of Apicultural Research, 52(1), 1-21. https://doi.org/10.3896/ IBRA.1.52.1.13

Jensen, A.B., Welker, D.L., Kryger, P., James, R.R. (2012). Polymorphic DNA sequences of the fungal honey bee pathogen Ascosphaera apis. FEMS Microbiology Letters, 330(1), 17-22. https://doi.org/10.1111/j.15746968.2012.02515.x

Koh, I., Lonsdorf, E.V., Williams, N.M., Brittain, C., Isaacs, R., Gibbs, J., Ricketts, T.H. (2016). Modeling the status, trends, and impacts of wild bee abundance in the United States. Proceedings of the National Academy of Sciences of the United States of America, 713(1), 140-145. https://doi.org/10.1073/pnas.1517685113

Lopes, L.Q.S., Quatrin, P.M., De Souza M.E., De Almeida Vaucher, R., Vianna Santos, R.C. (2015). Fungal Infections In Honey Bees. Fungal Genomics \& Biology 4(1), 1-4. https:// doi.org/10.4172/2165-8056.1000118 
Louveaux, I., Maurizio, A., Vorwhol, G. (1978). Methods of melisso-palynology by International Commission of Bee Botany of IUBS. Bee World, 59(3), 139-157. https://doi.org/10.1080/0005772x.1970.11097312

Lundgren, J., \& Jurat-Fuentes, J. L. (2012). Physiology and ecology of host defense against microbial invaders. In Insect Pathology. (pp. 461-480). 2nd Ed. University of Tennessee, Knoxville.

Maxfield-Taylor, S.A., Mujic, A.B., Rao, S. (2015). First detection of the larval chalkbrood disease pathogen Ascosphaera apis (Ascomycota: Eurotiomycetes: Ascosphaerales) in adult bumble bees. PLOS ONE, 10(4), e0124868. https://doi.org/10.1371/journal. pone.0124868

Méndez, M.V., Sánchez, A.C., Flores, F.F., Lupo, L.C. (2016). Análisis polínico de mieles inmaduras en el sector oeste de las yungas de Jujuy Argentina. Boletín de la Sociedad Argentina de Botánica. 57(3), 449-462. https://doi.org/10.31055/1851.2372.v51. ก3.15390

Nganso, B.T., Fombong, A.T., Yusuf, A.A., Pirk, C.W., Stuhl, C., Torto, B. (2017). Hygienic and grooming behaviors in African and European honeybee, New damage categories in Varroa destructor. PLOS ONE, 12(6), e0179329. https://doi.org/10.1371/journal. pone.0179329

Ollerton, J., Winfree R., Tarrant S. (2011). How many flowering plants are pollinated by animals? Oikos, 120(3), 321-326. https://doi.org/10.1111/j.16000706.2010.18644.x

Palacios, M.A., Clemente, G., Ruffinengo, S., Escande, A.R., Peña, N. (2007). Viability and pathogenicity of Ascosphaera apis preserved in integral rice cultures. Spanish Journal of Agricultural Research, 5(4), 481486. https://doi.org/10.5424/sjar/2007054-284

Pereira, K.S., Meeus, I., Guy, S. (2019). Honey beecollected pollen is a potential source of Ascosphaera apis infection in managed bumble bees. Scientific Reports, 9(4241), 1-9. https://doi.org/10.1038/ s41598-019-40804-2
Porrini, P.L, Quintana, S., Brasesco, C., Porrini, M., Garrido, M., Eguaras, M., Fernandez Iriarte, P. (2020). Southern limit of Africanized honey bee in Argentina inferred by mtDNA and wing geometric morphometric analysis. Journal of Apicultural Research, 59(4), 648-657. https://doi.org/10.1080/00218839. 2019.1681116

Principal, J., D'Aubeterre, Barrios, R, Carlos Puzzar, C." García de la Rosa, S., Fuselli, S.R., (2008). Hygienic behavior of africanized honeybees (Apis melliera scutellata Lepeletier) in apiaries of Lara State. Venezuela. Zootecnia Tropical, 26(2), 167-173.

Reynaldi, F.., López, A.C., Albo, G.N., Alippi, A.M. (2003). Differentiation of Ascosphaera apis isolates by repPCR fingerprinting anddetermination of chalkbrood incidence in Argentinean honey samples, Journal of Apicultural Research, 42(4), 68-76. https://doi.org/10 .1080/00218839.2003.11101096

Reynaldi, FJ, Lucia, M., Garcia Genchi, M.L. (2015). Ascosphaera apis, the entomopathogenic fungus affecting larvae of native bees (Xylocopa august): First Report in South America. Revista Iberoamericana de Micología. https://dx.doi.org/10.1016/j. riam.2015.01.001

Rivas, F., \& Bettucci L. (2007). Frecuencia y abundancia de Ascosphaera apis y otras especies de hongos en las colmenas de Apis mellifera de Uruguay, Journal of Apicultural Research, 46 (1), 1-2. https://doi.org/10.1080/00218839.2007. 11101358

Shin, Y.K., \& Kim, K.Y. (2016). Macelignan inhibits bee pathogenic fungi Ascophaera apis growth through HOG1 pathway. Brazilian Journal of Medical and Biological Research, 497), e5313. https://doi. org/10.1590/1414-431X20165313

Siva-Jothy, M.T., Moret, Y., Rolff, J. (2005). Insect immunity: An evolutionary ecology perspective. In Advances in Insect Physiology (pp. 1-48). https://doi. org/10.1016/s0065-2806(05)32001-7

Takatori, K., \& Tanaka, I. (1982). Ascosphaera apis isolated from chalkbrood in honey bees. Nihon Chi- 
kusan Gakkaiho. 53, 89-92. https://doi.org/10.2508/ chikusan.53.89

Teerayut, T., \& Chantawannakul, P. (2008). Protease and $\beta$-N-acetylglucosaminidase of honey bee chalkbrood pathogen Ascosphaera apis. Journal of Apicultural Research, 471), 68-76. https://doi. org/10.3896/ibra.1.47.1.11

Tejerina, M.R., Cabana, M.J., Flores, J.M., Benítez-Ahrendts, M.R. (2019). Studies of Ascosphaera apis strains isolated from commercial pollens of different Spanish provinces and their enzymatic production capacity. Archivos de Zootecnia, 68(263), 324-330. https://doi.org/10.21071/az.v68i263.4189

Wang, P., \& Granados, R.R. (2000). Calcofluor disrupts the midgut defense system in insects. Insect Biochemistry and Molecular Biology, 3022), 135-143. https://doi.org/10.1016/s0965-1748(99)00108-3

Wynns, A.A. (2012). The bee specialist fungus family Ascosphaeraceae and its allies: systematics, ecology and co-evolution with solitary bees. Ph. D. thesis, Department of Agriculture and Ecology, University of Copenhagen. Denmark.
Wynns, A.A., Jensen, A.B., Eilenberg J. (2013). Ascosphaera callicarpa, a New Species of Bee Loving Fungus, with a Key to the Genus for Europe. PLoS ONE, 8(9), e73419. https://doi.org/10.1371/journal. pone.0073419

Zuluaga, C.M., Quicazán, M.C., Serrato, C.J. (2015). Valoración de la calidad microbiológica de polen apícola sometido a diferentes tratamientos térmicos. Retrieved July 8, 2020, from http://investigacion. bogota.unal.edu.co/fileadmin/recursos/direcciones/ investigacion_bogota/documentos/enid/2015/memorias2015/ingenieria_tecnologias/valoracion_de_ la_calidad_microbiologica_de_.pdf 